\title{
Study of SME Technology Venture Investment Mechanism
}

\author{
Hongxin Li, Mengchun Ding \\ School of economic and management \\ Changchun University of Science and Technology \\ Changchun, China, 130012 \\ lihongxin18@sohu.com
}

\author{
Guojing Pei \\ 11th graduate student, School of economic and \\ management \\ Changchun University of Science and Technology \\ Changchun, China, 130012
}

\begin{abstract}
From the microscopic point of view of enterprises, this paper defines the relevant concepts of the mechanism of SME Technology Venture Capital, and puts forward the six mechanisms of financing mechanism, investment mechanism, regulatory mechanism, risk control mechanism, the mechanism of return and exit mechanism, and then it shows its own thinking about the construction of the six mechanisms.
\end{abstract}

Keywords-SME; Technology Venture Capital; Investment Mechanism; Financing mechanism

\section{INTRODUCTION}

SME Technology Venture Capital plays an increasingly prominent role of national innovation, technological progress and solving the employment. This paper starts from the microscopic point of view of enterprises instead of from the Government's macroscopic perspective to explore the construction of SME Technology Venture Capital mechanism on the base of profound understanding of connotation of SME Technology Venture Investment Mechanism and the right idea.

\section{CORRECT UNDERSTANDING OF THE CONNOTATION OF} THE MECHANISM OF SME TECHNOLOGY VENTURE CAPITAL

\section{A. Connotation of Science and Technology Venture Capital}

Venture investments typically regard high-tech and highgrowth small and medium enterprises as objects to provide funds and venture management services for them ${ }^{1]}$. The value-added services that they offer and unique incentive and restraint mechanisms provide a basis for technology start-ups and development of SMEs.

The connotation of SME Technology Venture Capital should include the following aspects: (1) based on entrepreneurship, it could take the entire science and technology start-ups as the business objects instead of direct investment in research and development, (2) the investment of combination of funding and management,(3) the investment objectives put particular emphasis on high growth of entrepreneurial enterprises to gain high capital value-added returns rather than product sales profits, interest or dividends,(4) the initial investment, investments take the timely exit to gain value-added investment for the purpose from the intended beginning of investment, (5) the nature of the capital is private equity capital,(6) investment operators are professional venture capitalists, (7) the risk preference of investors is risk acceptance, which is an investment of both high risk and high yield, is a positive investment rather than a negative gambling, (8) withdrawal ways of investment: public offering (IPO), the sale of shares to a third party (trade sale), the repurchase of entrepreneurs (buy back) or liquidation, (9) an investment that can not obtain funds from traditional sources and there is no guarantee,(10) an investment of the combination of finance and technology,and(11) SME Technology venture enterprises have no limitation of funds, which will greatly reduce the threshold and vigorously push forward its development.

\section{B. Technology Venture Investment System}

The so-called technology venture investment system is the sum of a variety of institutions intrinsically linked to venture capital activities (subject and object), mechanism and system. From the participating subjects of venture capital, it mainly involves: venture capital investors (supply subject of venture capital funds), venture capitalists (the subject of venture capital operation) and entrepreneurs (the subject of venture capital needs).

Therefore, the main links of venture capital contain: entrepreneurs look for venture capital investors; venture capital investors invest it through venture capitalists; After the investment, venture capital investors will seek to an effective incentive and supervision for venture capitalists in order to make their own investment income be protected and maximize; entrepreneurs are the founders of entrepreneurial venture, before the venture capital enters into the enterprise, he is the operator of business; after the entry of venture capital in inappropriate times, venture capitalists will be professional managers instead of entrepreneurs to become the actual operators of the enterprise. The core behavior of the entrepreneurs is to play an innovative and entrepreneurial function and financing for start-ups. The relationship between the three main behavior subjects in the technology venture capital is summed up to the investment and financing relationship and motivation and supervision relationship in reality. The relationship between the three is shown in Figure 1. 


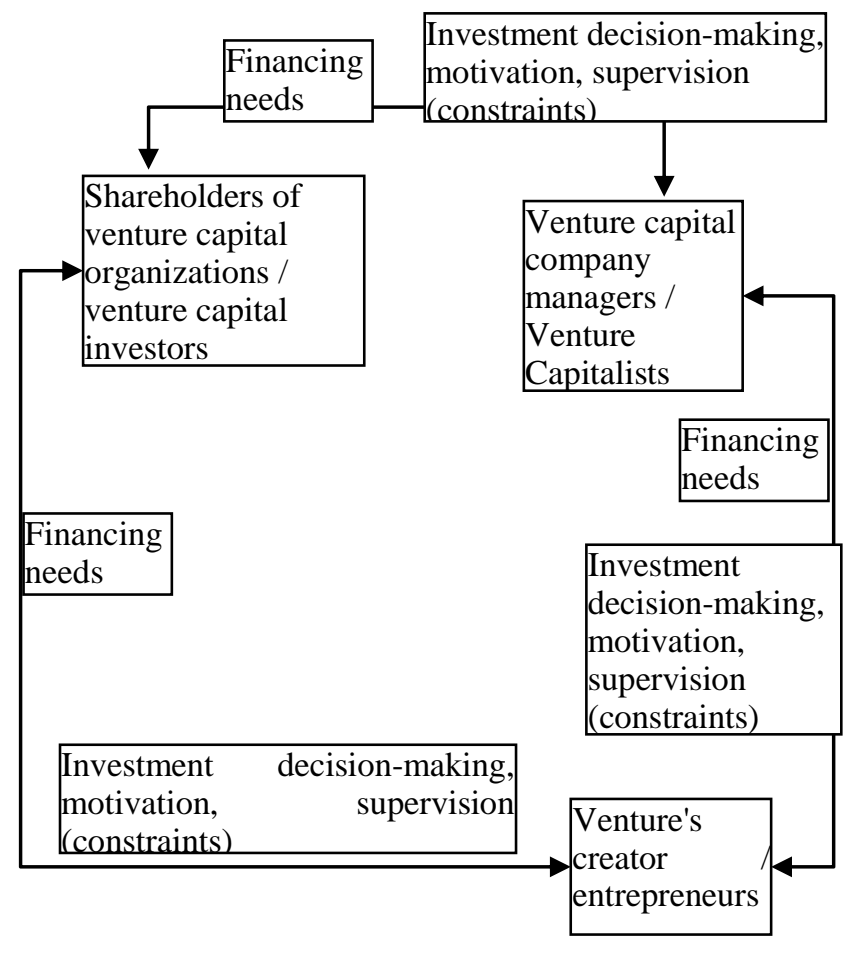

Figure 1. Relationship between venture capital investors, venture capitalists and entrepreneurs

\section{SME Technology Venture Capital Mechanism}

From a business perspective, the SME Technology Venture Investment Mechanism includes financing mechanism, management mechanism, investment mechanism, risk control mechanism, revenue mechanism and exit mechanism.

Financing mechanism: the most important issue to solve is the source of funds for venture capital and quantity. Therefore, only the establishment of more venture capital organizations to attract more funds could reduce the threshold of investment to meet the SME Technology Venture Capital Requirements.

Management mechanism: SME Technology Venture Capital has dual agency relationships of venture capital investors to venture capitalists and venture capitalists to venture enterprises, and thus produce the corresponding principal - agent risk, which requires that venture capital organizations and start-ups should have a unique company governance structure and mechanism. ${ }^{[2]}$

Investment mechanism: to identify investment projects. As for how to determine the projects, venture capital institutions have a very strict set of specialized operational processes, which generally include two main steps of project selection and project evaluation.

Risk control mechanism. SME Technology Venture Capital is different from other investments and the most prominent feature is the high risk, there are certain risks in all aspects of the venture capital operation.
Revenue mechanism: the revenue mechanism of venture investment varies from the different exit means that venture capital companies choose.

Exit mechanism: Successful exit is the key to assure the high return investors, the final exit investment needs decide all aspects of venture capital cycle including the ability to raise capital and the investment types.

\section{SME TECHNOLOGY VENTURE CAPITAL MECHANISM CONSTRUCTION}

\section{A. Financing Mechanism}

The financing mechanism is the most important issue with the most literature studies therefore. But it is far from the real SME Technology Venture Investment Services, so we should lower the threshold of the service. To solve the financing problem fundamentally is the operation method to find the market. The four modes to solve financing problems in our country: Shenzhen model;Shanghai model; Beijing Zhongguancun mode ${ }^{[3]}$;Hangzhou model ${ }^{[4]}$. Revelation of the four financing models:

It takes the private capital as the subject for multichannel financing. The subject of private investment and private enterprise meets the objective economic laws of development of venture capital; it also plays a particularly important role in guiding private capital. Sunshine of private capital enters into the channels of financial supervision for practical services for SMEs, and the space of floating interest rate can increase to reduce its tax and to encourage enterprise groups, financial institutions and foreign investors to participate.

To establish a market-oriented financing mechanism is the inevitable requirement for development of venture capital. Sources of venture capital funding are mainly provided by the capital markets to form the market mechanism of interdependence and mutual restraint among investors, investment managers and venture companies.

The security company should play a major role.

Enterprises Credit System includes the credit system, credit services product, service agencies, credit information system and incentive mechanism, its construction is the source and foundation to crack the financing puzzle.

\section{B. Management Mechanism}

Limited partnership is the best choice of venture investment fund, which combines capital and professionals together effectively and organically, and improves decisionmaking professional standards on the basis of a clear division of responsibility, right and profit. It not only encourages and restrains the venture capitalists' behavior, but also reduces the risks and responsibilities that the limited partners shall bear. In this kind of company, contributive persons are referred to as "limited partners", while capital operation managers by pioneering investment experts are referred to as the "general partners".

Entrepreneurial firms refer to the entrepreneurial pioneering enterprises with both high growth and high risk in the start-up stage. Entrepreneurial firms should focus on a combination of reward and purchase of stock rights, establish 
the incentive system of pioneering entrepreneurs, and convert part of the net worth of corporate assets growth to the corresponding equity to reward them based on entrepreneurial actual contribution to enterprises in the past as the recognition of their values.

\section{Investment Mechanism}

The selection mechanism of venture capital project can be summarized as follows: wide application, screening for many times, enough evidences and project approval; the followed requirements are: in accordance with the investment direction; standards of technical content; a certain business prospect.

Through the selection, only a small amount of the projects will be preserved and then enter into the investment appraisal stage. This stage has four important evaluation factors: the industry of start-ups, the stage, location and quality of entrepreneurs. They should truly establish a scientific project assessment system, given different weights of various factors based on the specific circumstances of the selected projects, and then follow the principle of stratified analysis to carry out comprehensive and scientific evaluation of investment projects with the scoring assessment of experts to entrepreneurial projects to realize the standardized operation of project selection assessments. At the same time, after the investment, they should establish a dynamic project evaluation mechanism to carry on a timely assessment and determine the additional investment and other issues.

\section{Risk control Mechanism}

1) To establish risk control indicators system: To refer to and learn from the risk assessment system of related projects to establish a system of risk control indicators (Figure 2-1) and corresponding countermeasures (Table 2-1).



Figure 2. Risk control index system of SME Technology Venture Investment Project

TABLE I. ANALYSIS OF RISK CONTROL MEASURES OF SME TECHNOLOGY VENTURE CAPITAL

\begin{tabular}{|c|c|c|}
\hline Risk types & Specific problems & Management plans \\
\hline $\begin{array}{l}\text { Technical } \\
\text { risk }\end{array}$ & $\begin{array}{c}\text { too high cost } \\
\text { Technical details } \\
\text { Outdated technology }\end{array}$ & $\begin{array}{c}\text { Cost-benefit analysis } \\
\text { Intensify efforts to } \\
\text { develop } \\
\text { To stop investment }\end{array}$ \\
\hline $\begin{array}{c}\text { Managemen } \\
\text { t risk }\end{array}$ & $\begin{array}{l}\text { Day-to-day management } \\
\text { Mismanagement } \\
\text { Too high regulatory costs }\end{array}$ & $\begin{array}{c}\text { The use of management } \\
\text { expertise } \\
\text { Decision-making } \\
\text { mechanism adjustment } \\
\text { Integration and } \\
\text { adjustment of } \\
\text { management team }\end{array}$ \\
\hline $\begin{array}{l}\text { Product } \\
\text { risk }\end{array}$ & $\begin{array}{c}\text { Raw materials are not } \\
\text { satisfactory } \\
\text { Outdated equipment } \\
\text { Process is not ideal } \\
\end{array}$ & $\begin{array}{c}\text { Wide range of } \\
\text { procurement } \\
\text { To update the device } \\
\text { To improve the process }\end{array}$ \\
\hline $\begin{array}{l}\text { Market } \\
\text { risk }\end{array}$ & $\begin{array}{c}\text { Ineffective marketing } \\
\text { channels } \\
\text { Lack of competitiveness } \\
\text { No market competitiveness }\end{array}$ & $\begin{array}{c}\text { To re-design marketing } \\
\text { strategies } \\
\text { Price replacement or } \\
\text { series products } \\
\text { introduction } \\
\text { To prepare a liquidation } \\
\text { plan } \\
\end{array}$ \\
\hline $\begin{array}{c}\text { Finance } \\
\text { risk }\end{array}$ & Lack of liquidity & Finance analysis \\
\hline $\begin{array}{l}\text { Policy } \\
\text { risk }\end{array}$ & Policy changes & $\begin{array}{c}\text { To pay attention to } \\
\text { policy } \\
\text { To study policy }\end{array}$ \\
\hline
\end{tabular}




\section{2) The risk control before venture capital investment:}

a) Venture investors and venture capitalists sign a perfect contract. Venture capitalists are required to provide the operation situation of the venture capital and a valuation report of the venture enterprise regularly and to make a disclosure to shareholders about the development or the progress of the project of relevant innovative products in a timely manner. At the same time, the investment contract can make restrictions for the application of the venture capital.

b) Risk control of venture investment and decisionmaking: First, the portfolio approach. An investment fund is invested in the independent projects of different types and different industries respectively; second, to take joint investment; third, to rely on the professional team assessment; fourth, phased investment.

c) Property rights constraints to strengthen risk control. Enterprise investment institutions gain some or all property rights of the enterprise when offering funds to hightech enterprises in the way of Investitionsbeteiligung, and ensure the monitoring rights of the business management, which reduces the risk of the venture capital to some extent.

3) The risk controls after the venture capital into startups:

a) The use of effective investment contract to control risk. Investment contracts are a binding agreement for both sides of investment and financing. Venture Capitalists could design the form of investment, investment tools, exit arrangements and the system requirements of entrepreneurial enterprise in the agreement to reduce the degree of information asymmetry between the two sides, and transfer a part of the Venture Capitalists' risk to start-ups so as to inspire entrepreneurship enterprises and the venture capitalists to share both the profits and the risks.

b) Strict implementation of the business plan to control the risk: If they find the management direction of venture business deviate from the plan or start-ups do not complete the goals of periods, they should immediately find out the reason and solve the problem.

\section{4) Other notes}

Venture capital firms should establish a good regulatory system, strengthen the monitoring and management of the risk of investment projects to prevent the moral risk caused by asymmetric information.

a) In the process of venture capital, they should carry out further analysis and testing on all the premises and assumes of the business plan in order to achieve the target accuracy.

b) In the governance arrangement of venture enterprises, they should give full play to the role of the enterprises themselves, but should continue to improve the incentive mechanisms and restraint mechanisms; in the management, they should specially supervise the valueadded services. c) In the management of entrepreneurial enterprises, venture capital firms should send managers with professional technical capacity, management capacity and the ability of risk value-added service. This prevents managers to interfere the company too much, but also can reduce the adverse effects of the information asymmetry on the company.

d) Start-ups should provide financial and management data regularly to venture capital firms in order to analyze and adjust the high-tech enterprises and improve the day-to-day operations and management of investment projects.

e) Establishment of the Committee's decision-making mechanism to avoid risks: Venture capital firms should be equipped with several unique institutions such as expert committees, technical experts, financial experts, management experts, financial experts, legal experts and other professionals to conduct a comprehensive and scientific assessment of investment projects and to provide advisory services for the formation company's management; Risk Management Committee and the Project Management Committee.

\section{E. Income Mechanism}

To select the revenue of the sharp appreciation of the stock value of the exit of initial public listing (IPO); to select the venture capital gains of share repurchases exit, the repurchase price of ordinary shares are consulted in advance by venture capital firms and repurchases to determine in the form of the agreement. Due to a variety of forms of the stock pricing, some economic indicators of start-ups are usually regarded as the basis of the stock pricing; to choose the risk revenue in the $\mathrm{M}$ \& $\mathrm{A}$ exits, in order to ensure the best purchase price, venture capital firms could use the methods of market efficiency, future reduction of the profitability, surplus multiples and accounting evaluation to determine the value of the acquired start-ups; the choice of liquidation exit is practicable in accordance with the contract.

\section{F. Exit Mechanism}

Initial public offering (IPO):The best way to the exit is public offering, which is also the exit way with the highest return on investment. It maintains the independence of the company after the listing, and entrepreneurs can re-retrieve the control of the company from the hands of venture capitalists. At the same time, IPO could meet the needs of start-ups to raise funds and the desire of fluidity.

Sale: the sale includes two main forms: company acquisition and financial acquisition. The company acquisition refers to acquiring and merger of start-ups by another company; financial acquisition is the acquisition of start-ups by another venture capital company to continue to invest after the acquisition. For those smaller companies and businesses, the sale of this exit strategy is a good choice.

Share repurchases: Share repurchases have many advantages, for example, the decision-making process is relatively simple, it is able to attract strategic investors for investment, the process is quick, it can isolate the volatility 
of private equity market to a certain extent, it could protect the interests of venture capitalists to some extent, so the buyback is also an important exit channel for SME technology capital. Start-ups could adopt the following ways for share repurchases: cash and notes, the establishment of the Employee Stock Ownership Fund, to sell share options and to buy share options.

Liquidation or bankruptcy: Such withdrawals are usually the choices with no way, but in many cases, they are the measures that venture capitalists must take drastically.

In general, the more successful venture capital enterprises develop, the more ways the capital exit will have; the more rapid the exit process is, the higher the value-added degree of the exit will be. Successful venture capital enterprises often realize the exit of venture capital through the IPO and other ways of high value - added degree; more and more less successful venture capital enterprises achieve the exit of venture capital by means of repurchase and other ways of low value - added degree; if the stock market has not yet developed to a certain stage, to select the acquisitions and mergers seem to be more realistic.

\section{REFERENCES}

[1] Venture Capital. Baidu Baike, http://baike.baidu.com/view/29225.htm, 2012

[2] Yang Xucai, "Funding sources of China's venture capital and study of the principal-agent problem" [D], Tianjin University, 2008

[3] Cui Junqiang, Zhang Duo, Ren Feng. "Three measures of Zhongguancun to crack the difficulty of technology-based small and medium and micro-enterprise loans". XinhuaNet, 2011

[4] Xu Ping, Xu Zhuoheng. " Hangzhou solves financing difficulties of technology-based SMEs, the risk pool fund helps the SMEs. Zhejiang network, 2011

[5] Guo Rong. " Revolution of enterprise technological innovation model under the promotion of venture capital mechanism", Journal of Beijing Normal University (Social Science Edition), 2009,5

[6] Xue yongji. " An Empirical Study of the Effects of Financing ways on the Performance of Technology Entrepreneurial Enterprise", Economics and Management Study, 2010 (11) 